\title{
Religion and Religiosity in Contemporary Poland
}

\author{
Dariusz Wadowski
}

https://doi.org/10.14712/25704893.2019.2

\begin{abstract}
Abstrakt: Článek se věnuje problematice změn, které se odehrávají v současném Polsku v oblasti náboženské víry, náboženských zvyků a obecně role náboženství i katolické církve. Autor předkládá vybraná data získaná během nedávných sociologických výzkumů, které jasně ukazují trend oslabování náboženské angažovanosti, nárůstu náboženského pluralismu, individualizace a privatizace náboženství i oslabování významu institucionalizované církve. Vzdor tomu, že článek sleduje jisté tendence, kterými se vývoj ubírá, nelze doopravdy odhadnout, zda a jak se tyto trendy zrealizují v budoucnu. Ve světle prezentovaných výsledků je však jasné, že katolická církev v Polsku musí hledat nové formy pastorální péče a nový způsob existence $\mathrm{v}$ životě polské společnosti.
\end{abstract}

Klíčová slova: náboženství; náboženskost; sekularizace; Polsko; sociologie náboženství

\begin{abstract}
The article addresses the problem of changes that are currently taking place in the field of religious beliefs, religious customs and the role of religion and the Catholic Church in Polish society. The author presents selected data from sociological research conducted in recent years, which quite clearly show trends of weakening religious engagement, increase in religious pluralism, individualization and privatization of religion, as well as weakening the importance of the institutional Church. Although certain tendencies are outlined, it is unpredictable what their further course will be. In the light of the presented research results, it is clear that the Catholic Church in Poland must look for new forms of pastoral care and new forms of presence in the life of Polish society.
\end{abstract}

Keywords: religion; religiosity; secularization; Poland; sociology of religion

Received: 8 April 2019, Accepted: 15 May 2019

Published online: 31 January 2020

Dariusz Wadowski, The John Paul II Catholic University of Lublin, Poland

E-mail: darwad@kul.pl 


\section{Historical outline}

Poland adopted Christianity in 966 and this date marks the foundation of Polish statehood. The baptism of the contemporary ruler of the tribes inhabiting part of the contemporary Polish territory was conducted through an intermediary of the Czech state and signified the country's entrance into the sphere of influence of the western Latin division of Christianity. Since the very beginning, the Catholic Church, through its institutions - its dioceses, parishes, and religious orders, actively contributed to forming the institutional structures of the state and its civilizational and cultural development.

Medieval times meant building close connections with the centres of Christianity in Western and Southern Europe. Towards the end of the medieval era, the Polish state, under the rule of the Jagiellons, became one of the largest European monarchies. Along with its territorial expansion it became a multi-ethnic and multi-religious organism, with the following religions thriving within its borders: the eastern Orthodox Church, Judaism, and Islam. The Protestant Reformation in the 16th century, though it encompassed a considerable share of the contemporary population of the Nobility Commonwealth citizens, did not cause any deep social divisions or conflicts stemming from religious attitudes.

Polish rulers adopted a concept of regulating interreligious relations, which differed from that of Western Europe where bloody religious wars broke out, by basing it on the principle of freedom of conscience. The influence of Protestant reformers was quite effectively curbed, undoubtedly due to the threat posed by neighbouring countries representing creeds and confessions other than Catholicism (Islamic Turkey, eastern Orthodox Russia, Protestant Sweden). The 17th century saw the rise of an unprecedented union between the Catholic Church and a part of the Orthodox Church, with the purpose to erase the divide between the eastern Orthodox Church and Catholicism. The newly founded Greek Catholic Church (Uniate) developed mainly in the east of the Polish Commonwealth of that time (these are predominantly territories lying now within Ukraine and Belarus).

At the end of the 18th century Poland was partitioned between three invaders: Russia, Prussia, and Austria, with the first two representing religions different from Roman Catholicism, dominant in the Polish Commonwealth. During the partitioning period, Polish national identity became very strongly fused with the Catholic religion, resulting in the formation of the stereotype of a Pole-Catholic. After Poland regained independence in 1918, the Roman Catholic creed was decidedly the dominant one in all social strata, and especially so amongst the most numerous worker and peasant class. World War II, which commenced on the 1st of September 1939, with Hitler's Germany attacking Poland, brought extensive human and material losses to the Church in Poland. A large part of the clergy was exterminated in German death camps and concentration camps. One of the better-known heroes of these times was the Polish Franciscan monk Friar Maksymilian Maria Kolbe, who sacrificed his life for a fellow prisoner in the Auschwitz Camp. 
After 1944, when the Communists came into power in Poland, religion became one of the main enemies of the state. Persecution and organised laicisation, especially of youth, did not have marked effects. The contemporary cardinal of Poland, Stefan Wyszyński, arrested for a period of time by the Communist government, adopted the strategy of resistance to Communism, resorting to folk religiosity and widespread ministry. In 1978, Cardinal Karol Wojtyła was elected Pope and assumed the name of John Paul II. This was an event of enormous importance, both for the Polish Church and the entire Polish society suffering the hardships of Communist oppression.

The Pope's pilgrimage to Poland in 1979 mobilised great numbers of participants, not only from among orthodox Catholics, and is nowadays commonly regarded as the impulse that laid the foundations for the Solidarity movement, which emerged a year later. This exceptional mass movement emphasized many religious symbols, notions, and other elements, closely tied to national themes. The political changes of 1989 reinstated democracy in Poland and also meant the Catholic Church regained its former position. The church used its representatives, the broad involvement of its institutional structures, and intensive ministry activities, and thus actively participated in building Polish national identity and defended it in difficult moments.

With the Catholic Church assuming the role of the primary resistance factor in the totalitarian state, it is usually pointed out that the strategies it relied on during the Communist regime and in the period that followed differed. ${ }^{1}$ In Communist times the main focus was simply on the survival of the Church as an institution, on supporting the believers in face of repression, and on retaining them against the state's atheism. During the following period, the actions of the Church were generally aimed on rebuilding and reformulating the national identity in accordance with the ideals of democracy and civic empowerment. Presently, with a rise of pluralism, globalist tendencies, market economy, and commercialism, alongside liberalism and moral relativism, its goal is to retain believers in the sphere of religious orthodoxy and to prevent secularisation.

\section{Outcomes of research in the field of religion and religiosity}

The presented study used mainly research by the CBOS (Public Opinion Research Center), which has several advantages. Firstly, these are surveys conducted on Polish nationwide representative samples, which means their outcomes can be extrapolated onto the whole of Polish society. Sample groups commonly include ca. 1000 Polish adults. Secondly, the studies are conducted using the same or very similar method over many years, thus making it possible to compare and observe changes over time. The second source were the results of the World Value Survey from 1989, 1997, 2005,

1 M. Tomka, "Catholics and Protestants in Post-Communist Europe", in I. Borowik (ed.), Religious Churches and Religiosity in Post-Communist Europe, Kraków: Instytut Wydawniczy "Nomos” 2006, p. 37-51. 
and 2012, also based on representative samples and offering the possibility to draw comparison with other countries included in the research. Not all European countries participated in those surveys, so complete comparisons are impossible. The third main source were the official statistics of the Catholic Church, compiled annually by the Institute of the Catholic Church Statistics SAC in Warsaw. Moreover, a number of works by sociologists of religion were used, offering inspiring interpretations of the present situation of religion and religiosity in Poland.

\section{Mono-religious Polish society}

According to the last General Census in Poland (2011), 96.0\% of respondents answering the question on their religious affiliation declared that they belonged to the Roman Catholic Church, $0.4 \%$ to the Eastern Orthodox Church, $0.4 \%$ to the Jehovah's Witnesses, $0.2 \%$ to the Augsburg Evangelical Church, and $0.1 \%$ to the Greek Catholic Church (Catholic Church of Byzantine-Ukrainian Rite). No affiliation to any religion was declared by $2.6 \%$. The religious structure of Polish society is therefore by and large monolithic. The representatives of religions and cults other than Christianity constitute less than a thousandth of the total population and persons without any religious affiliation constitute a small percentage. It is worth noting that the representatives of Christian denominations other than the Catholic one are very unevenly distributed within the country: the Eastern Orthodox Church believers and Greek Catholics inhabit mainly the east of Poland, while Protestants generally live in the west and north-west.

The number of Catholics within the entire Polish society is more or less stable, although in recent years a small decrease has been noted. In the World Value Survey data from 2012, 92.3\% of respondents perceived themselves as Catholics, in 2005 it was $94.4 \%$, and in $199793.5 \%$. The proportions of people declaring non-religious status were as follows: $4.7 \%, 2.0 \%$ and $3.1 \%$ (WVS'97, WVS'05, WVS'15 respectively). It can therefore be formally accepted that $90 \%$ of Polish population are Catholics. This means Poland has the highest proportion of Catholics from all the countries subject to WVS research in 2012. For example, in Germany Catholics account for $26.6 \%$, in Spain for $72.3 \%$, while in the Netherlands they take $17.6 \%$.

In a Polish nationwide survey conducted by CBOS in 2014, $89.3 \%$ of adult respondents declared themselves as Roman Catholics, $4.9 \%$ declared Christianity (in general), $1.6 \%$ atheism and the same number said they were simply non-religious, $0.7 \%$ stated that they did not belong to any religious denomination and $0.2 \%$ that they were agnostics. Agnosticism, atheism, or religious indifference is relatively rare among Poles. ${ }^{2}$

2 R. Boguszewski (ed.), Lokalna parafia - jest spoteczne znaczenie ifunkcje, CBOS Report 158 (2014), p. 1 . 


\section{Religious auto-declaration}

In case of religious auto-declarations considering obedience of the Church's recommendations, fairly significant changes are visible. The number of those considering themselves to be believers and compliant with the recommendations of the Church fell from $66 \%$ to $39 \%$ between 2005 and 2014, while the number of those who perceive themselves as religious people in their own way grew (from $32 \%$ to $52 \%$ ), as did the number of non-religious people (from $1 \%$ to $5 \%$ ).

Table 1: Religious auto-declaration of the Polish between 2000-2012 (\%). ${ }^{3}$

\begin{tabular}{l|l|l|l|l|l|l|l|l|l}
\hline Response categories & $\mathbf{2 0 0 0}$ & $\mathbf{2 0 0 3}$ & $\begin{array}{l}\mathbf{2 0 0 5} \\
\mathbf{( 0 2}\end{array}$ & $\begin{array}{l}\mathbf{2 0 0 5} \\
\mathbf{( 0 5 )}\end{array}$ & $\mathbf{2 0 0 6}$ & $\mathbf{2 0 0 7}$ & $\mathbf{2 0 0 9}$ & $\mathbf{2 0 1 0}$ & $\mathbf{2 0 1 2}$ \\
\hline $\begin{array}{l}\text { I am religious and I comply with } \\
\text { Church recommendations }\end{array}$ & 56.7 & 53.9 & 57.6 & 65.9 & 62.9 & 55.0 & 53.2 & 45.5 & 45.9 \\
\hline I am religious in my own way & 39.6 & 42.8 & 39.0 & 31.5 & 31.8 & 39.3 & 41.1 & 46.1 & 47.3 \\
\hline $\begin{array}{l}\text { I can't say whether I'm religous } \\
\text { or not }\end{array}$ & 1.3 & 1.0 & 0.6 & 0.8 & 1.7 & 2.4 & 1.6 & 3.2 & 2.2 \\
\hline $\begin{array}{l}\text { I'm not religious and I'm not } \\
\text { interested in it }\end{array}$ & 0.7 & 0.6 & 1.0 & 0.4 & 1.7 & 1.4 & 2.0 & 2.3 & 1.7 \\
\hline $\begin{array}{l}\text { I'm not religious because the } \\
\text { teachings of the Church are } \\
\text { mistaken }\end{array}$ & & & & & & & & & \\
\hline
\end{tabular}

Data from CBOS research indicate that since the nineties, the basic indicators of the declared faith have remained at a more or less identical level, although in this scope one could observe certain tendencies for change. The percentage of people declaring themselves as deeply religious in the period of 1997-2014 was contained within the range of $8 \%-12 \%$; as religious people moved in the range of $83 \%-87 \%$; and non-religious people were within the range of $3 \%-8 \%$. The decrease in the proportion of deeply religious people (between 2005 and 2014, the number declined by $4 \%$ ) is noticeable, as is the increase of the number of non-religious people (during the period of 2005-2014 by 3\%). While these shifts are not considerable, the tendency is clear and stable.

WVS research indicates that religion is an important value for Polish people. Almost half the respondents in 2012 considered it to be very important, and further $33.9 \%$ rather important in their life. This is one of the highest results in Europe. The percentage of respondents who state that religion plays a significant role in their life has stayed on a similar level since at least the end of the nineties, although there has been a slight increase in the number of respondents for whom religion is not important - from $16.2 \%$ in 1997 to $19.0 \%$ in $2012 .^{4}$

3 R. Boguszewski (ed.), Zmiany w zakresie wiary i religijności Polaków po śmierci Jana Pawła II. CBOS Report BS/49 (2012), p. 12. The categories: 'other' and 'difficult to say' were omitted.

4 R. Inglehart, C. Haerpfer, A. Moreno, C. Welzel, K. Kizilova, J. Diez-Medrano, M. LAgos, P. Norris, E. Ponarin \& B. Puranen et al. (eds.), World Values Survey: Round Three - Coun- 
Table 2: Importance of religion in selected European countries (\%). ${ }^{5}$

\begin{tabular}{l|l|l|l|l|l|l|l|l|l}
\hline $\begin{array}{l}\text { Importance of } \\
\text { religion in life }\end{array}$ & Belarus & Estonia & Germany & Netherlands & Romania & Spain & Sweden & Ukraine & Poland \\
\hline $\begin{array}{l}\text { Very important and } \\
\text { rather important }\end{array}$ & 48.0 & 25.3 & 38.0 & 25.2 & 83.8 & 32.1 & 26.2 & 60.8 & 79.6 \\
\hline $\begin{array}{l}\text { Not very important } \\
\text { and not at all } \\
\text { important }\end{array}$ & 50.8 & 73.1 & 61.7 & 72.7 & 15.9 & 67.1 & 72.8 & 39.3 & 19.9 \\
\hline
\end{tabular}

The cited WVS survey also contained questions on what religion means to the respondents in general. The surveyed Poles most often saw the essence of religion in good deeds unto other people (70.5\%), followed by imparting the purpose of life in this world (62.6\%), giving purpose to life after death $(25.8 \%)$, and finally observance of religious norms and ceremonies $(23.5 \%) .{ }^{6}$ In the light of this, one can state that the Polish appreciate the ethical dimension of religion more than the eschatological one.

\section{Religious practices}

The indicators of participation in religious practices are high as well, although there have been noticeable changes. The percentage of people practising regularly (several times a week and once a week) was between 50\% and 58\% in 1997-2014; for those practising irregularly (once or twice a month and several times a year) it is between $33 \%$ and $37 \%$, and for not practising it is between $9 \%$ and $13 \%$. There has been a noticeable decrease in the number of people practising regularly (by $8 \%$ during 20052014), and an increase of the number of people practising irregularly (by $4 \%$ during 2005-2014) and not practising at all (by 4\% during 2005-2014). ${ }^{7}$ After combining both variables (religious auto-declaration and participation in religious practices), it appears that the number of religious people who practise regularly fell from $58 \%$ to $50 \%$ in 2005-2014, while there was an increase in the number of religious people who practise irregularly (from $32 \%$ to $35 \%$ ), the number of religious people who do not practise (from $6 \%$ to $7 \%$ ), and the number of non-religious people who do not practise (from $3 \%$ to $6 \%$ ).

try-Pooled Datafile Version: www.worldvaluessurvey.org/WVSDocumentationWV3.jsp. Madrid: JD Systems Institute (2014), p. 6, V9; R. Inglehart, C. Haerpfer, A. Moreno, C. Welzel, K. Kizilova, J. Diez-Medrano, M. Lagos, P. Norris, E. Ponarin \& B. Puranen et al. (eds.), World Values Survey: Round Five - Country-Pooled Datafile Version: www.worldvaluessurvey.org /WVSDocumentationWV5.jsp. Madrid: JD Systems Institute (2014), p. 11, V9; R. InGLEHART, C. Haerpfer, A. Moreno, C. Welzel, K. Kizilova, J. Diez-Medrano, M. Lagos, P. Norris, E. Ponarin and B. Puranen et al. (eds.), World Values Survey: Round Six - Country-Pooled Datafile Version: www.worldvaluessurvey.org/WVSDocumentationWV6.jsp. Madrid: JD Systems Institute (2014), p. 11, V9.

5 Inglehart et al., World Values Survey: Round Six, p. 11 V9.

6 Inglehart et al., World Values Survey: Round Six, p. 344 V150, p. 346 V151.

7 R. Boguszewski (ed.), Zmiany $w$ zakresie podstawowych wskaźników religijności Polaków po śmierci Jana Pawta II, CBOS Report 26 (2015), p. 5. 
An important indicator of religiosity is the frequency of prayer. In 2015, it was recorded that $43 \%$ of Poles, surveyed by CBOS, prayed every day, $15 \%$ more than once a week, $8 \%$ once a week, $12 \%$ at least once a month, and $7 \%$ never. Compared to 2005 , the percentage of people praying every day decreased (by $13 \%$ ), with a rise in the number those who do not pray at all (by $2 \%$ ) and those who pray more often than once a week (by $4 \%){ }^{8}$

Taking into account the category of young people, treated as one particularly affected by secularisation tendencies, one can notice the trends which are found in the whole society are somewhat stronger. In 2005-2014 the proportion of people perceiving themselves as non-religious among respondents aged 18-24 rose (from 6\% to $15 \%$ ), while the number of religious people decreased (from $86 \%$ to $77 \%$ ), as did the number of regularly practising people (from $51 \%$ to $44 \%$ ), while the number of non-religious people in general increased (from $10 \%$ to $18 \%$ ). The proportion of people declaring themselves as religious and compliant with the recommendations of the Church (from $51 \%$ to $43 \%$ ) and the proportion of non-practising and non-religious people rose (from $4 \%$ to $11 \%$ ). In case of people from large cities, who are considered a category subject to faster secularisation, these tendencies are more conspicuous than in the population as a whole. During 2005-2014, the percentage of people describing themselves as deeply religious fell (from $12 \%$ to $8 \%$ ), as did the percentage of religious people (from $80 \%$ to $75 \%$ ), while the percentage of non-religious people increased percentage (from $8 \%$ to $17 \%$ ). The number of non-practising people also grew (rise from $17 \%$ to $23 \%$ ), while the number of religious and regularly practising people fell (fall from $43 \%$ to $36 \%$ ). ${ }^{9}$

The cited research shows certain fairly clear-cut tendencies, but it ought to be emphasised here that they are neither very far-reaching nor evenly distributed. In some cases the changes seem to be inhibited, and they may even move in the opposite direction. It is also noticeable that the dynamics of these changes are not very fast; they develop slowly over a longer period of time.

The World Values Survey showed that in 2012, 67.2\% respondents said they were going to church at least once a month; in 2005 it was $75.0 \%$; and in $199773.1 \%$. On the other hand the number of respondents who perceived themselves as religious reached, in the respective surveys: $90.9 \%$ in $1997,92.0 \%$ in 2005 , and $86.2 \%$ in 2012 . The decrease of the number of respondents who reported regularly attending church and declared themselves religious people is therefore confirmed here. Nonetheless, compared to other European countries, the level of auto-declaration as religious is still high. For example, the number of people declaring themselves as religious in 2012 reached $49.5 \%$ in Germany, $49.9 \%$ in Spain, $68.3 \%$ in Ukraine, and $43.8 \%$ in the Netherlands. ${ }^{10}$

${ }^{8}$ Boguszewski, Zmiany w zakresie podstawowych wskaźników..., p. 7.

${ }^{9}$ Boguszewski, Zmiany w zakresie podstawowych wskaźników..., p. 7-11.

${ }^{10}$ Inglemart et al., World Values Survey: Round Three, p. 258 V181, p. 259 V182; IngLeHART et al., World Values Survey: Round Five, p. 405 V186, p. 407 V187; IngLeHART et al., World Values Survey: Round Six, p. 336 V145, p. 340 V147. 
The official data of the Catholic Church, which conducts annual counts of the faithful attending the holy Sunday mass and receiving holy communion, shows that in 2014, 39.1\% of the faithful (dominicantes) attended mass, with $16.3 \%$ receiving holy communion (comunicantes). It is also possible to observe considerable territorial variation among the regions of Poland. The highest level of participation of the faithful in mass services was recorded in the following dioceses: Tarnów (70.1\%), Rzeszów (64.6\%), Przemyśl (59.6\%) and Kraków (50.7\%), while the lowest level of participation was found in the following dioceses: Sosnowiec (27.5\%), Koszalin-Kołobrzeg (25.8 \%), Szczecin-Kamień (24.9\%) and Łódź (24.8\%). The highest percentage of the faithful received holy communion in these dioceses: Tarnów $(24.3 \% \%)$, Opole (21.1\%), Zamość-Lubaczów (21.1\%), Pelplin (21.1\%), and the lowest in these dioceses: Szczecin-Kamień (11.3\%), Łódź (11.3\%), Sosnowiec (11.0\%) and Koszalin-Kołobrzeg $(10.8 \%)$. As can be seen, the differences between dioceses are sometimes as high as $100 \%$. Moreover, high participation of the faithful in the holy mass does not always indicate high numbers of people receiving holy communion - the differences between dominicantes and communicantes sometimes exceed $40 \%$, and on average they reach just above $20 \%$ in the whole of Poland, which denotes that more or less the same percentage of people go to church but do not receive holy communion. ${ }^{11}$

In comparison with previous years, one can notice that the percentage figures for the holy mass attendees have been systematically in decline, while the percentages of people receiving holy communion have been growing at the same time. These data can be interpreted as an expression of a greater harmonisation of the Catholics' religious identity and their wish to realise their religious involvement more fully.

Table 3: The numbers of the faithful attending the holy Sunday mass and receiving holy communion 1980-2014 (\%). ${ }^{12}$

\begin{tabular}{l|l|l|l|l|l|l|l|l}
\hline Indicator & $\mathbf{2 0 1 4}$ & $\mathbf{2 0 1 0}$ & $\mathbf{2 0 0 5}$ & $\mathbf{2 0 0 0}$ & $\mathbf{1 9 9 5}$ & $\mathbf{1 9 9 0}$ & $\mathbf{1 9 8 5}$ & $\mathbf{1 9 8 0}$ \\
\hline Dominicantes & 39.1 & 41.0 & 45.0 & 47.5 & 46.8 & 50.3 & 49.9 & 51.0 \\
\hline Communicantes & 16.3 & 16.4 & 16.5 & 19.4 & 15.4 & 10.7 & 9.1 & 7.8 \\
\hline
\end{tabular}

Polish people themselves have noticed the changes in the level of religiosity. In CBOS research, conducted 20 years after the democratic transformations in the newly independent Poland, $48 \%$ of respondents claimed that religiosity had declined, and twice fewer (22\%) claimed that it had grown throughout these years. ${ }^{13}$

While considering the issues of religion and religiosity amongst Poles, an important question is what the inhabitants of Poland actually believe in, what the contents and structure of their belief are, and what importance is assigned to transcendence in their faith.

${ }^{11}$ Annuarium Statisticum Ecclesiae in Polonia AD 2015, Warszawa: Instytut Statystyki Kościoła Katolickiego SAC 2015, p. 14.

12 Annuarium 2015, p. 17.

${ }^{13}$ R. BoguszewsKi (ed.), Od końca lat osiemdziesiatych do dziś - oceny zmian w różnych wymiarach zycia społecznego i politycznego w Polsce, CBOS Report BS/28 (2009), p. 2. 
Over half of the respondents questioned by CBOS in 2015 (56\%) stated that they definitely believed in God and had no doubts about His existence; $27 \%$ declared believing in God, although sometimes with moments of doubts; 5\% stated that sometimes it seemed to them that they believed in God, sometimes not; and 5\% said that they did not believe in a personal God, but they believed in some sort of higher force; $4 \%$ stated that they did not know if God existed and did not believe in the possibility of verifying it; and finally $3 \%$ said they did not believe in God at all. In comparison to previous years when similar research was conducted, it turns out that the percentage of people definitely believing in God decreased slightly (in 1997 - 61\%), while there was an increase in the percentage of those who sometimes had doubts (in 1997 $25 \%)$ and those who did not believe in God at all $(1997-1 \%) .^{14}$

Interesting information is gained by juxtaposing these data with the declarations of participation in religious practices. It turns out, for example, that amongst the people participating in religious practices several times a week $83 \%$ definitely believe in God. Amongst those participating once a week the number is $72 \%$, and amongst those participating once or twice a month it is $56 \%$. It is not, therefore, the case that all the church attendees have no doubts as to whether God exists and definitely believe in Him. The data clearly show that participation in religious practices is strongly correlated with belief in God: Religious people go to church more often while non-religious ones do not take part in religious practices.

In the international research of World Value Survey in 2012, $92.2 \%$ of the surveyed Poles declared that they believed in God, while $56.8 \%$ declared that they believed in Hell. ${ }^{15}$ Believing in God is thus more common than believing in hell. The level of believing in God in Poland is similar to that in Romania (92.3\%), and higher than in Germany (62.9\%), the Netherlands (71.1\%) or Sweden (40.9\%). The results show that Poland is not affected by secularisation trends to the same extent as Western European countries.

The World Value Survey data indicate that for the Polish, God is important. The average level of the importance of God in personal life, declared by Poles in 2012, was 7.95 (on a scale from 1 to 10). In 2005 it was 8.73 and in 1989 it was 8.78. Thus, we encounter a certain decrease of the importance of God in the life of Poles. For comparison regarding the importance of God in personal life: In the Netherlands this indicator was 4.37, in Germany 5.28, in Spain 5.0, in Sweden 3.65, and in Russia 6.68 (for 2012). The importance of God in life is higher among women than among men, and higher amongst older people than amongst younger ones. ${ }^{16}$

${ }^{14}$ R. Boguszewski (ed.), Kanon wiary Polaków, CBOS Report 29 (2015), p. 2.

${ }^{15}$ IngLehart et al., World Values Survey: Round Six, p. 342 V148, p. 343 V149.

${ }^{16}$ Inglemart et al., World Values Survey: Round Six, p. 349 V152; WV6_Results, Study \# Poland 2012_v20180912, p. 72 V152; Inglehart et al., World Values Survey: Round Five, p. 414 V192; R. Inglehart, C. Haerpfer, A. Moreno, C. Welzel, K. Kizilova, J. Diez-Medrano, M. LAGos, P. Norris, E. Ponarin and B. Puranen et al. (eds.), World Values Survey: Round Two Country-Pooled Datafile Version: www.worldvaluessurvey.org/WVSDocumentationWV2.jsp. Madrid: JD Systems Institute (2014), p. 174 V176. 
In the CBOS research in 2015, respondents were also questioned about their belief in life after death. What followed was that $36 \%$ of respondents think that after death we go to heaven, hell, or purgatory, $31 \%$ stated that there is something after death, yet no one knows what, $14 \%$ that after death there is nothing, it is the definitive end, $4 \%$ that we all go to Heaven, and $3 \%$ that we undergo reincarnation. Similarly to the previous case, the belief in Heaven or Purgatory after death is not common, even amongst those who practise regularly - it was declared by $57 \%$ of the people practising several times a week and $55 \%$ of those practising once a week. Those who do not practise are most often in favour of the thesis that after death there is nothing (55\%).

In spite of the fact that many people do not possess clear-cut convictions about life after death, most Polish people taking part in the discussed research stated that everyone could be delivered (61\%). Opinions that only religious people may be delivered $(8 \%)$ and definite declaration of disbelief in deliverance $(15 \%)$ were encountered relatively rarely. The faith in deliverance is also stronger than the convictions about life after death, and it is particularly ingrained amongst the regularly practising people.

In the cited research, there were also questions asked about other dogmas and religious ideas, of which most belong to the orthodox canon of Christian faith. $82 \%$ of respondents declared belief in God hearing prayers, $70 \%$ in the last judgment, $70 \%$ in heaven, $69 \%$ that man has an immortal soul, $62 \%$ in the resurrection of the dead, $59 \%$ in the original sin, $56 \%$ in Hell, $36 \%$ that animals have an immortal soul, and $30 \%$ in reincarnation. The presented data show that the faith of Polish people is to a certain extent syncretic, and combines elements originating in various, not necessarily Christian, religious traditions.

Still, the study mostly showed belief in dogmas and religious ideas pertaining to Christian orthodoxy. Using the global indicator of faith orthodoxy, based on all 12 categories applied in the cited study, it was concluded that it reached 7.33 on average (on a scale from 0 to 12), with the highest figures for the people practising several times a week (9.74) and, in comparison to other age groups, for young people (7.97). It shows that dogmas are absorbed most by those who go to church services often and those who recently attended religious education classes at school. ${ }^{17}$

\section{Parish and participation in parochial life}

The most important centre of religious life is the parish. CBOS research from 2014 indicates that for $66 \%$ of its participants it is the primary place of religious practices. The others either visit other parishes or only sporadically participate in religious practices. There is also a typical correlation between the size of the municipality in which people live and their frequency of practice in their parish: The larger the place of residence is, the more rarely people practise in their parish. ${ }^{18}$

${ }^{17}$ Boguszewski, Kanon wiary Polaków, CBOS Report 29 (2015), p. 4-9.

${ }^{18}$ Boguszewski, Lokalna parafia..., p. 4. 
The research allows also for establishing that the parish is not only a centre of religious life, but it meets other needs as well: It organises pilgrimages, holiday trips, and cultural, recreational, or sports events, it runs libraries, and provides material aid for the poorest people. In total, it was noted that $40 \%$ of respondents were beneficiaries of various parochial activities and initiatives. The respondents, however, are not fully knowledgeable with regards to the functioning of their parish. They perceive it primarily as an institution organising pilgrimages (86\%), administering aid for the poorest (67\%), and running its own website (61\%) and parochial newspaper (60\%). The image of the parish as a travel agency/pilgrimage operator, cultural organiser, and charitable aid manager is still the most frequent. Fewer than half of the people taking part in the research notice the functioning of the parochial council (45\%), and only slightly more than half of them perceive it as a place where prayer communities exist $(58 \%){ }^{19}$

Awareness of activities contributing to the parish is not very high, although they stretch out into other areas of social involvement. Such activities were mentioned by nearly one third of CBOS respondents. Most often they involve sporadic initiatives in the form of cleaning, renovating, fund raising, participation in organising and setting the scene for religious celebrations.

The subjective feeling of a bond with a parish is declared by two thirds of CBOS respondents (66\%). It ought to be noted, however, that in recent years the power of identification with a parish has been in decline: E.g. in 2005, a bond with the parish was declared by $80 \%$ of respondents. The given motivation for non-identification with the parish (such attitude was declared by $33 \%$ of respondents in the last survey) took most frequently the form of statements that it stems from not belonging to the Church, lack of faith, or because of specific reservations against the parish, e.g. that nothing is going on or that the parson is not liked very much.

Polish Catholics generally do not feel their impact on parochial matters is very significant, or that they have a say in the parish's functioning: $81 \%$ think that they have no such influence, with $44 \%$ definitely thinking so. It is also characteristic that, when asked whether they wish they had such influence, they usually responded that they have no such need ( $82 \%)$. This testifies to the fact that the Polish treat parishes more like service-providing institutions, and they feel no need to strongly engage in their affairs and functioning. ${ }^{20}$

\section{General image of the Church in Poland}

In general, Poles think that the situation in the Polish Church is good, with $68 \%$ of those polled by CBOS in 2015 saying so (including $10 \%$ recognizing it as very good). In comparison to 2013, the number of people thinking that it is good has increased

${ }^{19}$ N. Hipsz (ed.), Społeczna percepcja rzeczywistości parafialnej, CBOS Report 163 (2014), p. 2-4.
${ }_{20}$ Boguszewski, Lokalna parafia..., p. 19. 
(from 62\%). The situation in the Polish Church is, according to respondents, better than in the rest of Europe and worldwide. In relation to both Europe and the rest of the World, $58 \%$ of those surveyed recognized the situation as good. ${ }^{21}$

In 2013, CBOS conducted a survey which showed the image of the Polish Church in a different light. The respondents were asked what the main problems were that the Polish Catholic Church was facing. The most common answers were: pedophilia among clergy (43\%), homosexualism among clergy (29\%), Church's involvement in politics (28\%), loss of churchgoers, drop in religiousness (26\%), high living standards among clergy (23\%), and too high charges for sacraments (22\%). The image is therefore not as positive as it might seem. The next question concerned the main problems in the respondents' parishes. Here the most common answers were: too high charges for sacraments (18\%), loss of churchgoers, drop in religiousness (16\%), high living standards among clergy (10\%), Church's involvement in politics (8\%), expressing political sympathies during sermons (7\%). ${ }^{22}$ One can see that Poles see fewer problems on the parish level and that the pressure is conceived elsewhere. Therefore, one can assume that the views on the Polish Church in the Polish society are shaped strongly by the content presented in the media.

\section{Confidence in the Church}

The level of confidence in the Church can be an indicator of strong identification with the institution, but it can also show a weakness of this identification and, instead, a more widespread individualization of faith. ${ }^{23}$

The 2016 CBOS survey reports that $70 \%$ of the surveyed Poles had confidence in the Roman Catholic Church, including $24 \%$ who declared a great deal of confidence. This is a high index, as the Church is ranked 7 th among the 24 surveyed institutions. What is even more interesting is that Poles have more trust towards Caritas, the largest charitable organization run by the Church (83\%), than to the Church in general. Taking into account the long-term perspective, it appears that the level of trust towards the Church is relatively stable, although it has slightly decreased: In 2002 it was $76 \%$, in $200681 \%$, and in $201078 \%$. Poles have slightly lower trust towards their parish parson $-67 \%$ in 2016 . It can also be noted that this level of trust has slightly decreased when we take into account previous studies: In 2008 it was $72 \%$, and in $201069 \% .{ }^{24}$

Changes in the level of confidence in the Church as an institution are also illustrated by another study, The World Values Survey. In 1989 it had reported that 50.5\%

\footnotetext{
${ }^{21}$ B. Roguska (ed), Oczekiwane zmiany w nauczaniu Kościoła, CBOS Report 32 (2015), p. 4.

${ }^{22}$ K. PANKowski (ed.), O problemach Kościoła w Polsce, CBOS Report BS/145 (2013), p. 2-4.

${ }^{23}$ M. LibiszowsKa-ŻóŁTKowska, „Religia jako determinanta tożsamości studentów i konwertytów”, in M. Libiszowska-ŻóŁtKowsKa (ed.), Tożsamości religijne w społeczeństwie polskim: Socjologiczne studium przypadków, Warszawa: Difin 2009, p. 62.

${ }^{24}$ M. OmyŁa-Rudzka (ed.), Zaufanie spoteczne, CBOS Report 18 (2016), p. 14-16.
} 
of Poles had a great deal of confidence in the Church, and a further $31.9 \%$ of them had quite a lot of confidence. In turn, in 2012 it had been stated that the Church was 'strongly trusted' by $19.9 \%$, while $38.4 \%$ 'rather trusted' it. The overall decline in those who trust the Church was thus almost $25 \%$. Meanwhile, the percentage of those who did not have trust in the Church had increased: from 1.9\% ('do not trust') in 1989 to $9.0 \%$ in 2012. ${ }^{25}$ In 1989 the Church was the most trustworthy institution in Poland, which is no longer the case today.

\section{Political involvement of the Church and its place in public life}

According to the provisions of the Polish constitution, "public authorities in the Republic of Polish shall be impartial in matters of personal conviction, whether religious or philosophical, or in relation to outlooks on life, and shall ensure their freedom of expression within public life". Every once in a while, more or less heated debates take place regarding the presence of religion and the Church in social life, the role carried out by them, and potential restrictions in this matter. These debates relate primarily to whether the broadly understood public sphere should be completely free from religious influences, remain in isolation against the Church, religion and world views by leaving these matters to individual choices of citizens, or whether it should be open and an accessible space for the expression of ideas and religious beliefs, the display of symbols, and the expression of values which are important to community life.

According to the respondents surveyed by CBOS in 2015, Poland is a country where religious freedom is generally respected - this is what $85 \%$ of the surveyed stated. However, a less common belief is the general conviction of the ideological neutrality of the state - an opinion expressed by $64 \%$. Reservations regarding both principles are put forward primarily by people who are not involved in religious practices and who are non-believers. ${ }^{26}$

The CBOS 2013 survey examined attitudes towards the presence of religious symbols in public spaces. Respondents mostly tolerated quite a large presence of religious elements and the Church itself in the public sphere. For example, $88 \%$ of respondents said that they were not offended by the presence of the cross in offices or schools, $85 \%$ were not offended by the religious nature of the military oath, $82 \%$ by religious education classes in schools, $80 \%$ by the participation of priests and bishops in state rites and ceremonies and $76 \%$ by priests blessing sites and public buildings. Slightly bigger doubts were presented towards the tendency of priests to make statements about how to vote in the elections ( $82 \%$ were offended by this practice), to make statements on the position of the Church on laws passed by the

${ }^{25}$ Inglemart et al., World Values Survey: Round Two, p. 270 V272; IngleHART et al., World Values Survey: Round Six, p. 223 V108.

${ }^{26}$ B. Roguska (ed.), Katolik $w \dot{z y y c i u ~ p u b l i c z n y m ~-~ p o t e n c j a l n e ~ k o n f l i k t y ~ n o r m ~ i ~ w a r t o s ́ c i, ~ C B O S ~ R e-~}$ port 45 (2015), p. 5-6. 
parliament (55\% were offended), and the statements of the Church on moral issues and customs (33\% were offended). Taking into account the longer period of time since the research was carried out on this subject (since 1995), it can be noticed that despite small fluctuations between certain years, the overall trends are similar. Thus, it is possible to say that Poles have a relatively high acceptance for different, although not all, forms of the Church's presence in public life. Mirosława Grabowska affirms that 'crosses and priests are simply a Polish cultural landscape..$^{27}$ The significant majority of Poles approve of this model, while the discussions and disputes relate to more specific issues.

Debates on the subject of presence of religious symbols in public spaces took place in 2011. Similar discussions, although carried out a bit earlier, took place in other European countries as well (e.g. Italy, 2009). A CBOS survey conducted at the time confirmed that for the vast majority of respondents (88\%), the cross is nothing offensive in a public building like a school or office. Slightly fewer respondents felt that the cross should hang in the Chamber of Parliament (60\%). However, some stated that, since the parliament includes representatives of different faiths, there should not be any religious symbols there (36\%), while others claimed that there should also be symbols of different religions (19\%). Most Poles (56\%) also deem that the presence of the crucifix in public places can not be considered a violation of the rights of non-believers. ${ }^{28}$

The high stability of the Poles' opinion on these subjects, also confirmed during surveys in 2015, is noteworthy. ${ }^{29}$

A CBOS survey from 2014 showed that, when it comes to specific parishes that respondents belong to, there are not many cases of political engagement of priests: $61 \%$ of respondents stated that in their parish political agitation by the priests or them declaring their political views never happened, and a further $17 \%$ that it only happened occasionally. ${ }^{30}$ Allegations in terms of the Church influencing political life or being directly involved in it concern the Church rather generally and only a few of its representatives.

These cases, however, are usually heavily publicized by the media, which is why the Church is often seen as interfering in many spheres which are totally independent from faith. Examples of when an attempt to influence public affairs is attributed to the Church are often not related as directly to political, but rather to moral issues. The Church speaks on these matters in accordance with its doctrine or addresses politicians for preferred solutions. Usually, this is seen as 'unauthorized interfering in political affairs'.

${ }_{27}^{27}$ M. GRABowska (ed.), Religia i Kościót w przestrzeni publicznej, CBOS Report BS/170 (2013), p. 5.

${ }^{28}$ B. Roguska (ed), Obecność krzyża w przestrzeni publicznej, CBOS Report BS/153 (2011), p. 2-6.

${ }^{29}$ M. GrabowsKa (ed.), Boskie i cesarskie. O stosunkach między państwem i Kościotem(ami), CBOS Report 48 (2015), p. 5-6.

${ }^{30}$ Hipsz, Społeczna percepcja..., p. 10. 


\section{Religion and morality}

Many diagnoses concerning Polish religiousness indicate a growing distance between the teachings of the Catholic Church and the views of Poles concerning morality. ${ }^{31}$ According to sociologists, this is not the result of a rejection of the religious world view, but rather of the increasing selectivity and subjectivity of the moral sphere. Poles more frequently acknowledge that they can decide for themselves in regard to what is permitted or not, not necessarily following the indications of the Church and pastors.

In the CBOS studies mentioned earlier, concerning the involvement of the Church in public affairs, it was noted that $33 \%$ of respondents were discouraged by the outspoken positions of representatives of this institution on moral issues and moral customs. ${ }^{32}$ Grabowska interprets this fact as the specific discomfort that people feel towards an authoritative and non-empathetic style of Church statements. The distance of Poles towards accepting the moral guidance of the Church is quite clear however.

The results of research carried out by CBOS in 2013 report that $22 \%$ of Poles think that 'you should have clear moral principles and never depart from them', $42 \%$ that 'you should have clear moral principles, but in certain situations you depart from them', 19\% that 'you must have some moral principles, but there is nothing wrong with abandoning them due to the requirements of various situations in life', and $12 \%$ that 'your behavior should not be linked to predetermined moral principles, but you should, depending on the situation at hand, find appropriate ways of proceeding.' A large part of the respondents accept the rule of adapting behavior without having to take into account moral principles. ${ }^{33}$

On the other hand, answering the question of who should make judgements of good and evil, $19 \%$ replied that it should be decided by the law of God, $20 \%$ by the public, and $57 \%$ by each person individually within their own conscience. It is also worth noting that the percentage of those who believe that every person is the source of their own morality increased by 11 percentage points since 2005, while those referring to the laws of God declined by 8 percentage points. ${ }^{34}$

The subjectivity of moral principles is also visible when respondents comment on the issue of justification for these rules. $16 \%$ said that only religion can provide justifications for their correctness, 33\% that essentially religion justifies moral principles, but you might find other reasons, and $41 \%$ that they do not feel the need for any justification of moral principles other than their own conscience. Furthermore, only $14 \%$ of the surveyed felt that the moral principles of Catholicism are the best and constitute sufficient morality. More often, the respondents accepted the view that 'all principles of Catholicism are right, but in regard to the complexity of life they need to be complemented by other principles' (27\%) and that 'most moral principles of

\footnotetext{
${ }^{31}$ J. MARIAŃski, Religijność spoteczeństwa polskiego w perspektywie europejskiej: Próba syntezy socjologicznej, Kraków: Zakład Wydawniczy "Nomos” 2004, p. 321-382.

${ }^{32}$ Grabowska, Religia i Kościót..., p. 2.

${ }^{33}$ R. Boguszewski (ed.), Religijność a zasady moralne, CBOS Report 15 (2014), p. 2.

${ }^{34}$ Boguszewski, Religijność a zasady moralne, p. 3.
} 
Catholicism are right, however, they do not agree with everything', moreover 'those that are correct, are not sufficient for people' $(45 \%) .{ }^{35}$ These figures quite clearly confirm the thesis of the partial rejection of moral principles associated with Catholicism and that Poles increasingly look elsewhere for the justification of their morality.

There is more data concerning Poles' attitude towards chosen moral norms that show the concrete consequences of this individualized approach. In 2013, 77\% of surveyed Poles favored the acceptance of the use of contraceptives, $74 \%$ of sexual intercourse before marriage, $63 \%$ of divorce, and $27 \%$ of the termination of pregnancy. ${ }^{36}$

This last issue is a bit more complicated, because there are large discrepancies when it comes to different hypothetical reasons for abortion. An opinion poll from 2016 showed that $70 \%$ of respondents would allow for abortion when the life of the mother is in danger, $71 \%$ when her health is endangered, $73 \%$ when the pregnancy is the result of rape or incest, 53\% when it is known that a child will be born handicapped, $14 \%$ when a woman is in a difficult financial situation, $13 \%$ when she faces a difficult personal situation, and $13 \%$ when she simply does not want to have a baby. The possibility of abortion is thus accepted in a situation of danger to the mother or the baby or when the pregnancy results from rape, but is rather not permitted for the so-called social reasons or when it is the result of individual choice. ${ }^{37}$

What impact the Catholic Church has on the Poles' views in the area of morality is shown by the results of research carried out by CBOS, when heated discussions about the exacerbation of abortion law by the Parliament took place. The Polish Episcopate delivered its statement in the form of a letter which was to be read out to the faithful during Sunday Masses. It presented a clear and consistent position of the Church. The aforementioned studies were all performed twice: before the publication of the letter and after its publication. As it turned out, this letter essentially had no impact on the views of the respondents. ${ }^{38}$

\section{Religious relativism}

One of the factors that can significantly influence the shape of religiousness in Poland is religious relativism. ${ }^{39}$ It is one of the leading ideas characteristic for the New Age, which is sometimes called "religious universalism". However, it constitutes a threat to religious orthodoxy.

A CBOS survey from 2011 shows that $87 \%$ of respondents approved of the statement that 'every religion is equally good, if it helps a person live their life the best they can', 70\% agreed with the statement that 'God is worshiped in different religions

${ }^{35}$ Boguszewski, Religijność a zasady moralne, p. 7-9.

${ }^{36}$ Boguszewski, Religijność a zasady moralne, p. 13.

${ }^{37}$ M. Bożewicz (ed.), Dopuszczalność aborcji w różnych sytuacjach, CBOS Report 71 (2016), p. 2-8.

${ }^{38}$ Bożewicz, Dopuszczalność aborcji w różnych sytuacjach, p. 9.

${ }^{39}$ J. MARIAŃsKi, Kościót katolicki w Polsce a życie spoteczne. Studium socjologiczno-pastoralne, Lublin: Wydawnictwo Gaudium 2005, p. 289. 
regardless of what we call Him - Yahweh, Allah, etc., and He is really the same God', and $67 \%$ of the surveyed recognized that 'all religions lead to the same goal'. ${ }^{40}$ The measure of relativism has essentially remained at the same level since the end of the 90s, even though in comparison to similar surveys conducted in 1997 and 2006, the percentage of those agreeing with the second and third statement slightly decreased in the 2011 edition of the study.

On the other hand, the World Value Survey of 2012 shows that $37.3 \%$ of responding Poles accepted the statement that 'the only correct religion is my religion', while $53.2 \%$ agreed with the opposite statement. In comparison: In Germany, $28.8 \%$ believe only their own religion to be the correct one, in the Netherlands $13.3 \%$, in Romania $43.3 \%$, in Russia $30.1 \%$, in Ukraine $33.1 \%$, and $21.2 \%$ in the USA, while in Qatar this opinion was stated by $97.6 \%$, in Libya by $95 \%$, and in Jordan by $93.7 \%$. High rates of religious exclusivity exist in Islamic countries, while in Europe the legitimacy of other faiths and religions is mostly not denied. The index for Poland is slightly higher than in most European countries included in this study, but definitely closer to the pan-European level.

Nevertheless, $88.1 \%$ of respondents in Poland agreed with the statement 'people belonging to other faiths are probably just as moral as those belonging to my religion', whereas $4.2 \%$ did not agree with it. In Germany, this statement is accepted by $53.8 \%$, in the Netherlands by $60.6 \%$, in Romania by $71.7 \%$, in Russia by $64.5 \%$, in Spain by $66.3 \%$, and in the USA by $79.8 \% .^{41}$ The ratio in Poland is extremely high compared to other countries in the world, and Poland is comparable only to Australia (85.6\%) in this respect. It also shows the previously mentioned tendency that Poles usually separate morality and religion.

\section{The New Age and superstitions}

Detlef Pollack and Olaf Müller who had analyzed the results of studies concerning the popularity of the New Age in Central and Western European countries came to the conclusion that ideas associated with this new religious current covered only a minor part of the population of Poland. In view of the strong Church, faith in the ideas and values of New Age should be considered as an alternative form, and not as complementing the dominant religion. ${ }^{42}$ Representative polls show, however, that in Poland there is a fairly high level of acceptance of some elements of the New Age, which are sometimes combined with an orthodox Catholic faith.

${ }^{40}$ R. Boguszewski (ed.), Polacy wobec niektórych poglądów z kręgu New Age, CBOS Report BS/135 (2011), p. 5.

${ }^{41}$ InglehaRT et al., World Values Survey: Round Six, p. 353 V154, p. 357 V156.

${ }^{42}$ D. Pollack and O. MüLler, "Religiousness in Central and Eastern Europe: Towards Individualization?”, in I. Borowik (ed.), Religious Churches and Religiosity in Post-Communist Europe, Kraków: Instytut Wydawniczy “Nomos” 2006, p. 22-36. 
Previously cited data of CBOS from 2011 show that Poles do not treat their own religion exclusively, seeing it as the only path towards salvation. ${ }^{43}$ Poles also resort to divination and refer to traditional superstitions. In CBOS studies, respondents were presented with a set of claims. As it turned out, 59\% of respondents believed that some people had the ability of clairvoyance, $48 \%$ that some people had the ability to predict the future, $39 \%$ that there was another intelligent civilization somewhere in the universe, $39 \%$ that telepathy was possible, $34 \%$ that it was possible to cast an evil spell on someone, $33 \%$ that talismans brought luck, and $29 \%$ that the sign under which a person is born had a strong influence on the development of their character. What is characteristic is the fact that people defining themselves as deeply religious showed higher rates of acceptance for these statements than non-believers, and that the highest acceptance rate was recorded among the believers in 'one's own way'. A high acceptance was also noted among those who practice religion several times a week. ${ }^{44}$

The belief in superstitions is also quite popular in Poland, including things such as keeping your fingers crossed for someone's success, the belief in a chimney sweeper bringing good luck, the magical power of talismans, the luck of numbers 7 or 13, or bad luck brought by a black cat crossing the road. The most popular superstition is keeping your fingers crossed, meeting a chimney sweeper, or smashing a mirror. This was declared by more than $25 \%$ of respondents. Although the number of those declaring their belief in superstitions was not very high, it turned out that $56 \%$ of respondents had at least sometimes kept their fingers crossed, $45 \%$ of them knocked on wood, and $45 \%$ huffed on a coin they had found. The practice of superstitions is therefore more frequent than the faith in them. In this case it was also noted that the depth of the declared religious faith and regular religious practices have only minor effects on the belief in superstitions and the acts according to them. They are just some features of Polish culture which are absorbed in the process of socialization, and religious teachings do not invalidate them. ${ }^{45}$

\section{Religious customs during the holidays}

Polish Catholicism is very strongly associated with the customs of religious holidays. During the holidays, the importance of religion is shown publicly and religious practices have a mass character. Although during celebrations the importance of religious elements is not always dominant, the holidays are a way of upholding and passing on elements of religion and religiosity to the next generations. Moreover, during religious holidays the interconnected nature of religious and national traditions is perfectly visible.

The regularly conducted survey of Poles by CBOS shows that for almost half of the respondents (46\%) Easter is a religious experience. Most Poles, however, treat

\footnotetext{
${ }^{43}$ Boguszewski, Polacy wobec niektórych poglądów z kręgu New Age, p. 5-6.

${ }^{44}$ Boguszewski, Polacy wobec niektórych pogladów z kręgu New Age, p. 3.

${ }^{45}$ R. Boguszewski (ed.), Przesądy wciąż żywe, CBOS Report BS/130 (2011), p. 6.
} 
Easter as a family celebration (70\%). This type of research has been conducted since 1994, and we can observe that both the hierarchy of importance of the various ways of understanding Easter and the percentage of indications have been similar (though slightly fluctuating). However, there is a noticeable decrease in the number of those who see Easter as a religious holiday. The proportion of those who see it only as a secular holiday or purely focus on the practical aspect of the holidays is lower - about a quarter. ${ }^{46}$

Generally, Poles do prepare for Easter in some spiritual way: $84 \%$ fast on Good Friday, $68 \%$ go to the Easter confession, $65 \%$ have their head sprinkled with ash on Ash Wednesday, 59\% participate in the celebrations of the Easter Triduum, 57\% take part in Easter retreats, $52 \%$ in the Way of the Cross or Bitter Grievances and $48 \%$ participate in the Resurrection Mass on Easter Sunday. In general, Easter holidays are celebrated mostly religiously, even by those people not notably connected with the Church. This tendency is stable, and the only larger changes can be seen in the case of the number of people going to the Easter confession (a decrease of 11 percentage points between 2006 and 2016) and participating in the Resurrection Mass (a decrease by 12 percentage points). These two categories are closely related to spiritual life and have a strictly religious character, without as much of a relation to tradition. Consequently, the changes are rather important. A similar change in figures can be observed when it comes to the time of silencing yourself during Lent. Approximately $50 \%$ of respondents declare this practice, while back in 2010 it was over $60 \%$. This is where we can see the influence of consumer culture.

When it comes to the Christmas holidays, we can also see a similar tendency to combine the religious and family dimensions. In 2015, $23 \%$ of the CBOS respondents acknowledged Christmas as a religious holiday, whereas $54 \%$ saw it as a family holiday. Poles obey common customs associated with these holidays: $99 \%$ give each other Christmas greetings and wishes, $98 \%$ consume the special dishes during Christmas Eve, $98 \%$ share the Christmas wafer (a specific Polish custom), $86 \%$ retain the fasting during the Vigil (Christmas Eve, prior to the supper), 79\% sing Christmas carols, and $69 \%$ participate in the Midnight Mass. $69 \%$ of respondents go to confession and $67 \%$ say a prayer or read the relevant Bible passage before supper. ${ }^{47}$ Strictly religious customs are a little less common, but the religious component is present in all of the aforementioned, though not always fully realized. In the customs of Christmas, the growing influence of secular culture can also be seen for instance in the use of new technology to send Christmas wishes and in spending these holidays outside the family home, for example on holiday trips.

Religious customs still play an important role in the life of Poles, and the majority of them cannot imagine the important moments of life without religious ceremonies. $83 \%$ of the surveyed by CBOS in 2005 answered that the ceremony of their child's baptism was important, $81 \%$ that a religious wedding ceremony was import-

${ }^{46}$ M. Gwiazda (ed.), Wielkanoc, CBOS Report, 47 (2016), p. 2.

${ }^{47}$ R. Boguszewski (ed.), Boże Narodzenie 2015 - przygotowania do świąt i ich obchodzenie, CBOS Report 175 (2015), p. $3,7$. 
ant, and $85 \%$ that a religious funeral ceremony was important. While throughout the recent years the percentage of those who do not attach importance to the aforementioned rites has increased, there is a clear tendency that the most important moments in life should be accompanied by religious rites. ${ }^{48}$

\section{The significance of Pope John Paul II}

John Paul II is a person who has had a particular impact on the Polish society and the Polish Church at the end of the twentieth century and the early twenty-first century. In a study conducted by CBOS in 2011, $80 \%$ of respondents stated that the life and teachings of John Paul II contributed to the transformation of the lives of most Poles and $58 \%$ believed that he had also helped to transform their own lives. During these studies, prior to the beatification of John Paul II, respondents were asked about the meaning of this celebration. 95\% considered it an important event for all Poles, $83 \%$ considered it important for themselves personally, $71 \%$ considered it important for Europe, and $70 \%$ considered the beatification important for the whole world. ${ }^{49}$

The impact of John Paul II has many dimensions, including a religious dimension. The death of John Paul II in 2005 was considered a quite important moment. The surveys conducted then showed an increase in the basic indicators of religiosity which had reversed the former long-term downward trends. This increase, however, was short-lived, and in later years the trends have returned towards that downward direction. The level of declared faith and frequency of religious practices in Poland had declined since the death of Pope John Paul II in 2005. In the years 2005-2014, the number of people declaring themselves as believers and deeply religious decreased from $97 \%$ to $93 \%$, whereas the number of those practicing at least once a week fell from $58 \%$ to $50 \%$. The number of Catholics declaring themselves as believers and who follow to the indications of the Church fell from $66 \%$ to $39 \%$ and was accompanied by an increase in the number of those who consider themselves 'believers in their own way' (from $32 \%$ to $52 \%$ ). ${ }^{50}$

John Paul II continues to be at the top as a personal model and authority. In 2009, he was mentioned as a personal authority by $17 \%$ of those surveyed by CBOS, and $59 \%$ considered him to be the main authority in public life by placing him on the first spot. $^{51}$

Respondents surveyed in 2015 most frequently believed that despite the passage of 10 years since the death of the "Polish Pope" his memory still lives on among the general public (94\%) and that his teachings are generally known (71\%). Less frequently do they recognize that Poles follow the rules in life which were indicated by John Paul II (45\%). Speaking about themselves personally, they declared that they

\footnotetext{
${ }^{48}$ K. Kowalczuk (ed.), Sfery sacrum i profanum w życiu spotecznym, CBOS Report 31 (2015), p. 9.

${ }^{49}$ N. Hipsz (ed.), Czekając na beatyfikacje Jana Pawta II, CBOS Report BS/49 (2011), p. 2-3, 11.

${ }^{50}$ Boguszewski, Lokalna parafia..., p. 3.

${ }^{51}$ M. Hermann (ed.), Wzory i autorytety Polaków, CBOS Report BS/134 (2009), p. 5.
} 
were aware of the content of his teachings (70\%), and stressed that in their lives they follow those rules $(68 \%)$. Thus, Poles slightly more often declare themselves to be familiar with the teachings of John Paul II and follow them, rather than declare such an attitude among the general public..$^{52}$

The cited studies may lead to the conclusion that for most Poles John Paul II is a moral authority $-95 \%$ of respondents admitted that (including $65 \%$ who chose the option 'strongly'). This is a higher percentage than in the case of Pope Francis as a moral authority ( $84 \%$, including $43 \%$ who chose 'strongly'). Poles often mention John Paul II in their prayers and conversations (declared by $43 \%$ of respondents, including $11 \%$ as 'very often'), but the prayers asking for intercession on various issues is less common (34\%). ${ }^{53}$

These nationwide systematic studies indicate that the importance of John Paul II is slowly falling with the increasing length of time that has passed since his death. This is not a radical decrease, but it is taking place.

\section{Anticipated changes in the Church}

Attention is often paid to the problem of adapting the Church's teachings to the requirements of modern society and contemporary culture, as well as the needs and problems of believers. Discussions devoted to that have not left out Poland. Some communities formulate postulates towards the Catholic Church and other churches, sometimes far-reaching demands of greater openness to new problems and issues and adjustment in some of the contents of those teachings.

The results of research conducted in 2015, when in many countries and communities discussions were held on possible changes in relation to the Church's teaching concerning the family in connection with the ongoing 24th Synod of Bishops, suggest that Poles also expressed some expectations in this regard. According to $80 \%$ of the respondents the Church should allow individuals who are divorced and living in open relationships the ability to have the Holy Communion, $79 \%$ were in favour of allowing the possibility of the use of in vitro fertilisation, $73 \%$ of allowing the possibility to have an abortion in some cases, and $72 \%$ of allowing the use of contraceptives. $60 \%$ supported the idea of replacing individual confession with a collective one, and 59\% were in favour of abolishing celibacy. Less frequently, the respondents demanded the admission of women to the priesthood (37\%), to enable people living in homosexual relationships to receive the Holy Communion (32\%), and the admission of such people to the sacrament of marriage (16\%). This data show quite a serious rift between the Church's teaching and the views of the believers in Poland. ${ }^{54}$

\footnotetext{
${ }^{52}$ R. Boguszewski (ed.), Jan Pawet II w pamięci Polaków po dziesięciu latach od śmierci, CBOS Report 46 (2015), p. 1-4.

${ }^{53}$ Boguszewski, Jan Pawet II w pamięci Polaków..., p. 6-9.

${ }^{54}$ Roguska, Oczekiwane zmiany..., p. 6.
} 


\section{Certain issues defining the context of Polish religiousness}

\section{Emigration}

One of the most serious problems for the contemporary Polish society, which also has consequences in the area of religion, is mass economic emigration. Currently it is estimated that several million Poles reside abroad permanently or temporarily, mainly in Western Europe: in Great Britain, Germany, Ireland, the Netherlands, Belgium, and in Scandinavian countries. Official figures coming from the Catholic Church parish records talk about 2.7 million parishioners being abroad, which is approx. $8 \%$ of the total registered people in Catholic parishes. ${ }^{55}$ Emigrants leaving for work and to pursue a better standard of living often lose their religious roots. Many of them focus primarily on making and saving money and often stay in regions where access to churches and Catholic communities is difficult, where there is no possibility of having or using pastoral support in Polish, and as a consequence they quickly lose their religious tendencies. In some environments, migrants are also subject to serious loosening of moral standards, especially those relating to marriage and family life. An example of this may be temporary partnerships commonly established while abroad, arising either out of the need to share the rent for an apartment, or from attempts to compensate for experienced social isolation and loneliness. People with their own families in their homeland also tend to enter into such relationships, and the dramatic effects are visible upon their return from their economic emigration. For a large part of these emigrants, the only means and opportunity to maintain a connection with their religion are holidays and vacation periods, when they return to their homes. Prior to the larger religious holidays, airplanes and highways are usually full of Poles returning from Western Europe to celebrate with their families. Despite the fact that Poles treat holidays primarily as an opportunity to meet with the family, during the stay in their homeland, they massively participate in religious activities and practices that nurture religious traditions.

\section{Anti-religious and anti-Catholic trends}

Just like after obtaining sovereignty in 1989, till this very day, we have had to deal with rather strong anti-religious trends, especially against Catholicism. This is no doubt a result of the fact that Catholicism is the predominant religion and, in many cases, expansive, and that it publicly resists secular trends.

Many examples of such anti-religious activities can be found. In the 90 s a weekly newspaper, founded by the former advocate of the communist government during the martial law period, was considered very popular. Nowadays, some artists and cultural activists openly distance themselves from religion and express this position in their works, giving rise to many controversies among believers. During discussions about the abortion law, which come up again every once in a while, those in favor of making access to abortion easier by legal means usually consider the Catholic Church and its believers as their main opponent, regardless of what role they have during

${ }^{55}$ Annuarium 2015, p. 8. 
those discussions. Street demonstrations which took place in the fall of 2016, directed against the civil project of tightening the anti-abortion law and against the conservative government coalition which was currently in power, very strongly referred to the anti-religious and anti-Church rhetoric.

They usually take the form of ridiculing ideals and moral norms with religious underpinnings in a vulgar way, as well as sharp criticisms of actions of the Church hierarchy referring both to the traditional anti-clericalism arguments taken from some Enlightenment rationalism and from some positivistic trends. Arguments indicating the backwardness and parochialism of Poland in comparison to the more developed European countries are also common.

These cases are often broadly covered and widely publicized by the media. They appear both on the more liberal side, where they are usually more or less accepted, and in the more conservative media, where they are the subject of condemnation and indignation. Some liberal newspaper covers, which show the Church and clergy in very negative light, have caused major controversies throughout the entire population, especially among Christians.

The place where the most heated discussions take place, while at the same time being the place where it is the most difficult for opponents to find common ground, is the Internet. News or posts on the Internet concerning the life of the Church or generally related to issues connected with religion are usually accompanied by many anonymous comments, most of which are expressed aggressively. Commentators mostly cite many anti-religious stereotypes referring to the wealth of priests and the Church, of paedophilia among the clergy, irrationality and lack of novelty in religious beliefs, etc. Religious spokespersons rarely engage in these types of dialogues or even polemic discussions. For this reason, the most popular Internet news portals are quite largely controlled by anti-Christian rhetoric.

From time to time, some atheistic or anti-religious organizations engage in social campaigns which are aimed at promoting secular views and fighting off religion. One of these campaigns was titled 'You have a right to not believe', another had the slogan 'Atheists are divine'. These organizations oppose the teaching of religion in schools, the organization of nativity scene plays and Christmas meetings in schools and kindergartens, the presence of religious content in school textbooks and encourage apostasy.

Anti-religious and anti-Catholic trends are present in Poland, but they operate on the margins of mainstream society in a systematic way. There are numerous cases of direct aggression directed against symbols of religion, places of worship, religious representatives, and forms of manifestation of religious identity. It would be difficult to interpret them as having a mass character, since they usually do not have the power to give rise to society-wide anti-religious attitudes. The official data of the Catholic Church states that during the years 2012-2014, many forms of discrimination (e.g. offensive comments, beatings, etc.) were conducted on priests. $12.1 \%$ of the clergy was harmed, and in $8.7 \%$ of parishes there was some kind of desecration of holy places. ${ }^{56}$

${ }^{56}$ Annuarium 2015, p. 23. 


\section{Internal variation of Polish Catholicism}

Polish Catholicism is not homogenous and varies internally with regard to many different criteria. Sociological studies in Polish religiosity usually indicate the existence of significant differences between age categories, gender representatives, inhabitants of various environments (countryside - large cities) and regions of the country, followers of particular political parties, etc. Inside the all-encompassing current of Catholicism, discussions and disputes continue with regard to various components of ecclesial teaching, its position in public life, the manner of conducting ministry or the degree of the lay people's influence upon the life of the Church. Catholicism is an internally dynamic reality, with complicated relations between its elements and segments, subject to the impact of internal contexts while simultaneously exerting influence on the very same contexts. Without any doubt, it is not the monolith that it might seem to be.

For this reason, the sociologists of religion draw up certain typologies, facilitating a global insight into the state of religion and religiosity in Poland. One of such typologies, focusing primarily on Catholic religiosity, has been proposed by Janusz Mariański, who distinguishes seven basic categories of Catholics: ${ }^{57}$

1) Catholics with commitment, ecclesiastic and prayer activity, belonging to communities and movements participating in various forms of ecclesial teaching; aware of their faith, active in prayer and developing their life in a religious way. Mariański estimates their number at $10 \%$ of adults belonging to the Catholic Church.

2) People bound to the Church with formal ties, agreements, and fulfilling various functions in it working for the benefit of Church institutions (ca. 1\%).

3) Traditional and orthodox Catholics, practising ones, recognising dogmas of the faith and respecting the moral teachings of the Church, involved in the functioning of the parish, with attachment to national traditions and religious ceremonials. This category shows strong internal variation in many respects and the orthodoxy of its followers is variously motivated. It constitutes about $30 \%$ of Polish Catholics.

4) Selective Catholics, partially identifying with the dogmas of the faith and the moral doctrine of the Church, selecting elements suitable for them, practising sporadically and irregularly, consciously adopting the attitude of keeping a distance from the institutional dimension of religion and placing religion and religiosity fairly low in their hierarchy of values. According to estimates they account for about $30 \%$.

5) Open, progressive, liberal Catholics; fairly removed from orthodoxy, keeping distance from the association of Catholicism with the Polish national identity; often anticlerical and reforming in attitude, undertaking critical reflexion over the elements of Catholic culture and doctrine. They account for about $15 \%$.

57 J. MARIAŃski, “Tendencje rozwojowe religijności katolickiej w Polsce”, in E. FirLit, M. Hainz, M. Libiszowska-ŻóŁtkowska, G. Pickel, and D. Pollack (ed.), Pomiędzy sekularyzacją i religijnym ożywieniem. Podobieństwa i różnice $w$ przemianach religijnych $w$ Polsce i $w$ Niemczech, Kraków: Akademia Ignatianum, Wydawnictwo WAM 2012, p. 38-40. 
6) Nominal, marginal Catholics; baptised but practising only in special circumstances (holidays, religious celebrations), accepting religious education of their children at a basic level, but not identifying themselves with multiple components of the teachings of the Church and not deepening their religious awareness. They may account for about $15 \%$.

7) Borderline Catholics; distanced from God and the Church; actual atheists connected with the Christian tradition, not involved in the life of the Church and maintaining distance from faith, religion and moral teachings; yet formally they do not leave the Church. They account for about $2-3 \%$.

Perhaps the quantitative estimates referring to particular categories of Catholics are disputable, and for sure these categories are open-ended, without strictly limited boundaries, but still they show that Catholics in Poland do not constitute a homogenous and internally cohesive group. Further divisions may appear within particular categories, as Polish Catholicism is undergoing dynamic pluralisation. Among the reasons for this internal variation, one may point to reasons of more subjective nature (biographical particulars, consciously made decisions, character features), as well as to more objective ones (ministry activities of the Church, cultural tendencies, impact of the media). It is nonetheless clearly visible that ecclesial religiosity, remaining under institutional control, is only one of the forms of Polish Catholicism.

A slightly different typology is proposed by Christopher Grabowski after John Allen. ${ }^{58}$ Here, stronger emphasis is put on the public dimension of Catholicism, the participation of Catholics in public debates and political life. This typology is an attempt at answering the question of how Polish Catholics seek an answer to the challenges of modernisation. Garbowski distinguishes three categories of Catholics: liberal, evangelical, and Pentecostal. The first are open to everything which modernisation brings, and reject strict affiliation of religion with national identity; they talk about the necessity of adjusting the language and the contents of ecclesial teaching (especially any moral one) to the requirements of modernity, as well as about the necessity of more democracy in the Church and greater independence of the faithful. Evangelical Catholics are in turn more orthodox; they attempt to make the awareness of Catholics deeper; they demand greater personal commitment (also in missions); they are inspired by various elements of the tradition, and yet it is difficult to consider them conservative, since they actively seek new forms of propagating the evangelical message. Both of these categories of Catholics are relatively numerous and contain many groups, centres of ministry and associations, they are expressing their views in public debates loudly and clearly, using various means of social communication. Garbowski, however, draws attention to the fact that they make use of different discourse, which makes mutual understanding and cooperation difficult. Of the lowest importance in the public space are Pentecostal Catholics, who view Christianity in the category of apocalypse and the approaching end of all time.

${ }^{58}$ Ch. Grabowski, Religious Life in Poland, History, Diversity, and Modern Issues, Jefferson: McFarland \& Company 2014, p. 198-207; J. Allen, The Future Church: How Ten Trends are Revolutionizing the Catholic Church, New York: Doubleday 2009, passim. 
The transformations of Polish religiousness in the first several years of the 21st century may be interpreted by using different theoretical categories such as: 'the individualization of religion and religiousness', ${ }^{59}$ 'faith without affiliation' and 'affiliation without faith', ${ }^{60}$ shifts towards 'the invisible religion', ${ }^{61}$ 'collective identity', ${ }^{62}$ 'post-secularism', ${ }^{63}$ 'secularization connected with modernization', ${ }^{64}$ religion as 'remembrance and reversion towards tradition'. ${ }^{65}$ As it may seem, none of the aforementioned theoretical interpretations entirely exhaust the complication of the issue, nor constitute the whole picture. Thus, Mariański duly recognizes that any definitive statements in this domain are impossible, and further directions of changes are uncertain. ${ }^{66}$ Although certain tendencies are outlined, it is unpredictable what their further course will be. Various currents of secular trends which are connected to globalization and growing cultural pluralism, as well as the diffusion of secular elements from Western Europe, the secularized pop-culture commercialism and cosmopolitan market areas collide with the lively trend of Church evangelization, innovative forms of pastoral activities, activities of orthodox-Catholic groups or communities, Church and beyond-Church institutions, or new methods of Christian influencing and upbringing. Furthermore, religion in Poland and the religiousness of Poles cannot be detached from other elements of national culture and transformations which take place in its capacity. ${ }^{67}$ This study is merely a fragmentary outline of certain phenomena and processes which may be observed to this extent, and requires further thorough research.

${ }_{59}$ Pollack and Müller, "Religiousness in Central and Eastern Europe”, p. 22-36; Mariański, "Tendencje rozwojowe religijności katolickiej w Polsce”, p. 31-48.

${ }^{60}$ G. DAvie, Socjologia religii [The Sociology of Religion], Kraków: Zakład Wydawniczy "Nomos" 2010.

${ }^{61}$ T. Luckmann, Niewidzialna religia: Problem religii we wspótczesnym spoteczeństwie [The Invisible Religion: The Problem of Religion in Modern Society], Kraków: Zakład Wydawniczy “Nomos” 1996, passim.

${ }^{62}$ S. Jakelić, "Secularization, European Identity, and 'The End of the West', The Hedgehog Review $8(1-2,2006)$, p. $133-139$.

${ }^{63}$ U. PęKala, "Post-secular religious practices entering traditional religion", in T. AhLBÄCK and B. Dahla (ed.), Post-Secular Religious Practices: Based on papers read at the symposium on Post-Secular Religious Practices held at Äbo/Turku, on 15-17 June 2011, Äbo/Turku: Donner Institute for Research in Religious and Cultural History 2012, p. 274-288.

${ }^{64}$ F.-X. Kaufmann, Czy chrześcijaństwo przetrwa? [Wie überlebt das Christentum?], Kraków: Wydawnictwo WAM 2004; J. Casanova, J., "Rethinking Secularization: A Global Comparative Perspective", The Hedgehog Review 8 (1-2, 2006), p. 7-22.

${ }^{65}$ D. Hervieu-LÉGer, Religia jako pamięć [La Religion pour memoire], Kraków: Zakład Wydawniczy "Nomos" 1999, passim.

${ }^{66}$ J. MARIAŃski, “The Religiosity of Polish Society from the Perspective of Secularized Europe”, in I. Borowik (ed.), Religious Churches and Religiosity in Post-Communist Europe, Kraków: Instytut Wydawniczy "Nomos" 2006, p. 81-91.

${ }^{67}$ L. Dyczewski, Kultura polska $w$ procesie przemian [Polish culture in transition], Lublin: Towarzystwo Naukowe KUL 1995, p. 259-276; L. DyCzewski (ED.), Polish Philosophical Studies III: Values in the Polish Cultural Tradition, Washington: The Council for the Research in Values and Philosophy 2002, passim. 
Acknowledgements: This text was created as a result of "The Future of Religious Faith from Central European Perspective" project funded by the Templeton Foundation (www.budoucnostnabozenstvi.cz).

\section{References}

Allen, J., The Future Church: How Ten Trends are Revolutionizing the Catholic Church, New York: Doubleday 2009, $480 \mathrm{p}$.

Annuarium Statisticum Ecclesiae in Polonia AD 2015, Warszawa: Instytut Statystyki Kościoła Katolickiego SAC 2015, 24 p., available online at https://episkopat.pl /wp-content/uploads/2016/01/Raport-Annuarium-Statisticum-Ecclesiae-in -Polonia-2015.pdf.

Boguszewski, R. (ed.), Boże Narodzenie 2015 - przygotowania do świąt i ich obchodzenie, CBOS Report 175 (2015), 12 p., available online at https://www.cbos.pl/SPISKOM .POL/2015/K_175_15.pdf.

Boguszewski, R. (ed.), Jan Pawet II w pamięci Polaków po dziesięciu latach od śmierci, CBOS Report 46 (2015), 10 p., available online at https://www.cbos.pl/SPISKOM .POL/2015/K_046_15.pdf.

Boguszewski, R. (ed.), Kanon wiary Polaków, CBOS Report 29 (2015): 11 p., available online at https://www.cbos.pl/SPISKOM.POL/2015/K_029_15.pdf.

Boguszewski, R. (ed.), Lokalna parafia - jest spoteczne znaczenie i funkcje, CBOS Report 158 (2014): 21 p., available online at https://www.cbos.pl/SPISKOM .POL/2014/K_158_14.pdf.

Boguszewski, R. (ed.), Od końca lat osiemdziesiatych do dziś - Oceny zmian w różnych wymiarach życia spotecznego i politycznego w Polsce, CBOS Report BS/28 (2009), 9 p., available online at https://www.cbos.pl/SPISKOM.POL/2009/K_028_09.pdf.

Boguszewski, R. (ed.), Polacy wobec niektórych pogladów z kręgu New Age, CBOS Report BS/135 (2011), 14 p., available online at https://www.cbos.pl/SPISKOM .POL/2011/K_135_11.pdf.

Boguszewski, R. (ed.), Przesąy wciaż żywe, CBOS Report BS/130 (2011), 8 p., available online at https://www.cbos.pl/SPISKOM.POL/2011/K_130_11.pdf.

Boguszewski, R. (ed.), Religijność a zasady moralne, CBOS Report 15 (2014), 16 p., available online at https://www.cbos.pl/SPISKOM.POL/2014/K_015_14.pdf.

Boguszewski, R. (ed.), Zmiany w zakresie wiary i religijności Polaków po śmierci Jana Pawta II. CBOS Report BS/49 (2012): 25 p., available online at https://cbos.pl /SPISKOM.POL/2012/K_049_12.pdf.

Boguszewski, R. (ed.), Zmiany w zakresie podstawowych wskaźników religijności Polaków po śmierci Jana Pawła II, CBOS Report 26 (2015), 14 p., available online at https:// www.cbos.pl/SPISKOM.POL/2015/K_026_15.pdf.

Bożewicz, M. (ed.), Dopuszczalność aborcji w różnych sytuacjach, CBOS Report 71 (2016), 10 p., available online at https://www.cbos.pl/SPISKOM.POL/2016/K_071_16.pdf.

Casanova, J., "Rethinking Secularization: A Global Comparative Perspective", The Hedgehog Review 8 (1-2, 2006): p. 7-22.

DaviE, G., Socjologia religii [oryg.: The Sociology of Religion], Kraków: Zakład Wydawniczy "Nomos" 2010, 390 p.

Dyczewski L. (ed.), Polish Philosophical Studies III: Values in the Polish Cultural Tradition, Washington: The Council for the Research in Values and Philosophy 2002, 319 p.

Dyczewski L., Kultura polska w procesie przemian [Polish culture in transition], Lublin: Towarzystwo Naukowe KUL 1995, 310 p. 
Garbowski Ch., Religious Life in Poland, History, Diversity, and Modern Issues, Jefferson: McFarland\&Company 2014, 298 p.

Grabowska, M. (ed.), Boskie i cesarskie. O stosunkach między państwem i Kościołem(ami), CBOS Report 48 (2015), 11 p., available online at https://www.cbos.pl/SPISKOM .POL/2015/K_048_15.pdf.

Grabowska, M. (ed.), Religia i Kościót w przestrzeni publicznej, CBOS Report BS/170 (2013), 15 p., available online at https://www.cbos.pl/SPISKOM.POL/2013/K_170_13 .pdf.

GwiazDA, M. (ed.), Wielkanoc, CBOS Report, 47 (2016), 5 p., available online at https:// www.cbos.pl/SPISKOM.POL/2016/K_047_16.pdf.

Hermann, M. (ed.), Wzory i autorytety Polaków, CBOS Report BS/134 (2009), 6 p., available online at https://www.cbos.pl/SPISKOM.POL/2009/K_134_09.pdf.

Hervieu-LÉGer, D., Religia jako pamięć [oryg.: La Religion pour memoire], Kraków: Zakład Wydawniczy “Nomos” 1999, 252 p.

Hipsz, N. (ed.), Czekając na beatyfikację Jana Pawła II, CBOS Report BS/49 (2011), 12 p., available online at https://www.cbos.pl/SPISKOM.POL/2011/K_049_11.pdf.

Hipsz, N. (ed.), Społeczna percepcja rzeczywistości parafialnej, CBOS Report 163 (2014), 12 p., available online at https://www.cbos.pl/SPISKOM.POL/2014/K_163_14.pdf.

Inglehart, R., C. Haerpfer, A. Moreno, C. Welzel, K. Kizilova, J. Diez-Medrano, M. Lagos, P. Norris, E. Ponarin and B. Puranen et al. (eds.), World Values Survey: Round Two - Country-Pooled Datafile Version: www.worldvaluessurvey.org /WVSDocumentationWV2.jsp. Madrid: JD Systems Institute 2014, 476 p.

Inglehart, R., C. Haerpfer, A. Moreno, C. Welzel, K. Kizilova, J. Diez-Medrano, M. Lagos, P. Norris, E. Ponarin \& B. Puranen et al. (eds.), World Values Survey: Round Three - Country-Pooled Datafile Version: www.worldvaluessurvey.org /WVSDocumentationWV3.jsp. Madrid: JD Systems Institute 2014, 619 p.

Inglehart, R., C. Haerpfer, A. Moreno, C. Welzel, K. Kizilova, J. Diez-Medrano, M. Lagos, P. Norris, E. Ponarin \& B. Puranen et al. (eds.), World Values Survey: Round Five - Country-Pooled Datafile Version: www.worldvaluessurvey.org /WVSDocumentationWV5.jsp. Madrid: JD Systems Institute 2014, 879 p.

Inglehart, R., C. Haerpfer, A. Moreno, C. Welzel, K. Kizilova, J. Diez-Medrano, M. Lagos, P. Norris, E. Ponarin \& B. Puranen et al. (eds.), World Values Survey: Round Six - Country-Pooled Datafile Version: www.worldvaluessurvey.org /WVSDocumentationWV6.jsp. Madrid: JD Systems Institute 2014, 898 p.

JAKELIĆ, S., "Secularization, European Identity, and “The End of the West"”, The Hedgehog Review 8 (1-2, 2006): p. 133-139.

Kaufmann, F.-X., Czy chrześcijaństwo przetrwa? [oryg.: Wie überlebt das Christentum?], Kraków: Wydawnictwo WAM 2004, 160 p.

Kowalczuk, K. (ed.), Sfery sacrum i profanum w życiu społecznym, CBOS Report 31 (2015), 10 p., available online at https://www.cbos.pl/SPISKOM.POL/2015/K_031_15 .pdf.

LiBiszowska-ŻóŁtkowska, M., “Religia jako determinanta tożsamości studentów i konwertytów”, in M. LiBIszowska-Żó£TKowska (ed.), Tożsamości religijne w społeczeństwie polskim: Socjologiczne studium przypadków, Warszawa: Difin 2009, p. $46-63$.

Luckmann, T., Niewidzialna religia: Problem religii we wspótczesnym społeczeństwie [The Invisible Religion: The Problem of Religion in Modern Society], Kraków: Zakład Wydawniczy "Nomos" 1996, 155 p.

MARIAŃski, J., Kościót katolicki w Polsce a życie społeczne. Studium socjologicznopastoralne, Lublin: Wydawnictwo Gaudium 2005, 353 p. 
Mariański, J., “Tendencje rozwojowe religijności katolickiej w Polsce”, in E. Firlit, M. Hainz, M. Libiszowska-ŻóŁtkowska, G. Pickel, and D. Pollack (ed.), Pomiędzy sekularyzacją i religijnym ożywieniem. Podobieństwa i różnice w przemianach religijnych $w$ Polsce i $w$ Niemczech, Kraków: Akademia Ignatianum, Wydawnictwo WAM 2012, p. 31-48.

MARIAŃski, J., "The Religiosity of Polish Society from the Perspective of Secularized Europe”, in I. Borowik (ed.), Religious Churches and Religiosity in Post-Communist Europe, Kraków: Instytut Wydawniczy “Nomos” 2006, p. 81-91.

MARIAŃsKi, J., Religijność społeczeństwa polskiego w perspektywie europejskiej: Próba syntezy socjologicznej, Kraków: Zakład Wydawniczy “Nomos” 2004, 481 p.

OмyєA-RudzKa, M. (ed.), Zaufanie spoteczne, CBOS Report 18 (2016), 20 p., available online at https://www.cbos.pl/SPISKOM.POL/2016/K_018_16.pdf.

Pankowski, K. (ed.), O problemach Kościoła $w$ Polsce, CBOS Report BS/145 (2013), 10 p., available online at https://cbos.pl/SPISKOM.POL/2013/K_145_13.pdf.

PĘKALA, U., "Post-secular religious practices entering traditional religion”, in T. AHLB̈̈ск and B. Dahla (ed.), Post-Secular Religious Practices: Based on papers read at the symposium on Post-Secular Religious Practices held at ̈̈bo/Turku, on 15-17 June 2011, Äbo/Turku: Donner Institute for Research in Religious and Cultural History 2012, p. 274-288.

Pollack, D., and O. Müller, "Religiousness in Central and Eastern Europe: Towards Individualization?”, in I. Borowik (ed.), Religious Churches and Religiosity in PostCommunist Europe, Kraków: Instytut Wydawniczy “Nomos” 2006, p. 22-36.

Roguska, B. (ed), Obecność krzyża w przestrzeni publicznej, CBOS Report BS/153 (2011), 7 p., available online at https://www.cbos.pl/SPISKOM.POL/2011/K_153_11.pdf.

Roguska, B. (ed), Oczekiwane zmiany w nauczaniu Kościoła, CBOS Report 32 (2015), 10 p., available online at https://www.cbos.pl/SPISKOM.POL/2015/K_032_15.pdf.

Roguska, B. (ed.), Katolik w życiu publicznym - potencjalne konflikty norm i wartości, CBOS Report 45 (2015), 7 p., available online at https://www.cbos.pl/SPISKOM .POL/2015/K_045_15.pdf.

Tomka, M., "Catholics and Protestants in Post-Communist Europe", in I. Borowik (ed.), Religious Churches and Religiosity in Post-Communist Europe, Kraków: Instytut Wydawniczy "Nomos" 2006, p. 37-51.

WV6_Results, Study \# Poland 2012_v20180912, 139 p., available online at http://www .worldvaluessurvey.org/WVSDocumentationWV6.jsp. 